\title{
AN OVERVIEW OF DEPRESSION TENDENCIES IN PATIENTS WITH TYPE 2 DIABETES MELLITUS IN KEBONSARI PRIMARY HEALTHCARE CENTER, SURABAYA CITY
}

\author{
Iftitah Shofiyati \\ Departement of Epidemiology,Faculty of Public Health, Airlangga University, Surabaya, Indonesia \\ Corresponden Address: Iftitah Shofiyati \\ Email: iftitahshofiyati@gmail.com
}

\begin{abstract}
Type 2 diabetes mellitus (DM) occurs due to insufficient insulin production or insulin resistance in the human body. Type $2 \mathrm{DM}$ also causes physical weakness, vision problems, risk of death, and depression. This study aimed to describe depression tendencies in patients with type 2 DM under treatment in Kebonsari Primary Healthcare Center, Surabaya city. This study was a descriptive study with a cross-sectional approach. The research samples were 74 people with type 2 DM in the Kebonsari Primary Healthcare Center, Surabaya city. These respondents selected using simple random sampling had met the inclusion criteria. These repsondents were aged more than 25 years old, did not experience psychological disorders, and had suffered from type 2 diabetes mellitus for 5 years. The data analysis was done using a univariate analysis by looking at the frequency distribution of variables. The results indicate that the prevalence of patients with type $2 \mathrm{DM}$ who tended to experience depression was at $50 \%$. The majority of patients with type 2 DM who experienced depression were women (47.4\%) and elderly (aged 46-65 years) (41.9\%). Most of them had low education levels (62.2\%), and some respondents had complications (37.8\%) and poor family support (62.2\%). Support from closest people such as family support can improve the adaptation of patients with the disease and can prevent psychological disorders, especially depression in patients with type $2 \mathrm{DM}$.
\end{abstract}

Keyword: type 2 diabetes mellitus, family support, depression tendencies.

ABSTRAK

Penyakit diabetes mellitus tipe 2 adalah sebuah kondisi karena insulin yang diproduksi tubuh tidak cukup atau tubuh mengalami resistensi insulin. Diabetes mellitus tipe 2 dapat menyebabkan timbulnya kelemahan pada fisik, gangguan pengelihatan, risiko kematian dan depresi. Penelitian ini bertujuan untuk mengetahui gambaran tingkat kecenderungan depresi pada penderita diabetes mellitus tipe 2 di Puskesmas Kebonsari Surabaya. Penelitian ini adalah penelitian deskriptif dengan pendekatan cross sectional. Sampel berjumlah 74 penderita diabetes mellitus tipe 2 di Puskesmas Kebonsari dan termasuk dalam kriteria inklusi yang telah ditentukan, yaitu berusia lebih dari 25 tahun, tidak mengalami kelainan jiwa dan menderita diabetes mellitus tipe 2 selama lima tahun. Pengambilan sampel dilakukan dengan teknik simple random sampling. Teknik analisis data yang digunakan adalah analisis univariat dengan melihat distribusi frekuensi variabel. Hasil menunjukkan bahwa prevalensi penderita diabetes mellitus tipe 2 yang mengalami kecenderungan depresi sebesar 50\%. Responden yang mengalami kecenderungan depresi sebagian besar adalah perempuan (47,4\%), merupakan kelompok usia lansia (46-65 tahun) (41,9\%), memiliki tingkat pendidikan yang rendah (62,2\%), memiliki komplikasi $(37,8 \%)$ dan mendapat dukungan keluarga yang rendah $(62,2 \%)$. Dukungan dari orang terdekat salah satunya dari keluarga dapat meningkatkan adaptasi penderita dengan penyakitnya serta dapat mencegah timbulnya gangguan psikologis utamanya depresi pada penderita diabetes melitus tipe 2.

Kata kunci: diabetes mellitus tipe 2, dukungan keluarga, kecenderungan depresi.

\section{INTRODUCTION}

Diabetes mellitus (DM) causes metabolism disorders that lasts years and occurs due to the disability of the pancreatic organ to produce insulin to fulfill the body's needs or due to the disability of the body to effectively use the insulin produced (Indonesian Minsitry of Health, 2014). 
According to the Centers for Disease Control and Prevention (2017), diabetes is divided into three types, namely type 1 diabetes, type 2 diabetes, and gestational diabetes. In 2003, 194 million people suffered from DM, and the number increased to 200 million people in 2005 and 210 million people in 2010. The International Diabetes Federation (2013) report 5.6 million people in Indonesia suffered from diabetes in 2000 , and the number reached 8.5 million people in 2013. It is predicted to rise to 14.1 million people in 2035. Further, the Indonesian Ministry of Health (2013) shows that the DM prevalence that mostly occurs to people at the age of $>15$ years in Indonesia was at 1.5 percent. Specifically, in East Java province, the DM prevalence exceeded the national prevalence at 2.1 percent.

The number of DM incidents in Surabaya city steadily kept rising from 2016 to September 2018. The data from Surabaya District Health Office (2018) show that in 2016 the number of DM incidents was 105,208 incidents, which decreased to 102,599 cases in 2017, while in September 2018 it bounced back to 115,460 incidents. The highest number of patients with DM $(4,060$ incidents) in Surabaya received treatment $n$ from January to September 2018 in Kebonsari Primary Healthcare Center.

According to Handayani and Dewi (2009), people diagnosed with DM may experience physical and psychological disorders. These psychological disorders include depression, anxiety, irritability, irritability, and loss of will or interest to live. As stated by the WHO, depression is a mental disorder that causes several symptoms such as the feeling of depression, loss of joy and interest, guilty feeling for things, low selfesteem, horrible eating and sleep habits, difficulty in concentrating, and loss of energy. The effects of depression start to trigger when someone has been diagnosed with diabetes mellitus. Patients will behave contrary to prohibitions to control their diabetes. For example, they may not follow the dietary advice, do physical activity, stop smoking, and comply with the treatment schedule (Riley, et al. 2009).

Additionally, DM can worsen depression symptoms. Stress due to concerns in controlling diabetes and the effects of diabetes on the brain can contribute to depression. In the United States, a person who has diabetes mellitus is twice as likely to suffer from depression than general people. At the same time, the depression symptoms may reduce physical and mental health. For example, overeating causes an increase in body weight which is one of the risk factors for diabetes. Exhaustion and worthlessness may cause a person to ignore the special diet or medication needed to control diabetes. A study shows that people with diabetes and depression have more severe diabetes symptoms compared to people with only diabetes (National Institute of Mental Health, 2011).

Diabetes and depression correspond to each other. Depression may contribute to the low control of diabetes, its complications, and inadequate management of depression. Irregular control of diabetes will cause the blood glucose level to exceed its normal limits and finally result in various complications (Fatimah, 2015). Ceaseless DM complications may lead to prolonged depression. Chronic complications and difficulty of recovery in people with DM can lead to depression. Complications will limit one's activities in daily life and cause prolonged depression.

A study by Ramdani (2016) shows that patients with type $2 \mathrm{DM}$ experienced a certain degree of depression. As many as 82.3\% patients had no depression symptoms, $15.2 \%$ experienced mild depression, and $2.5 \%$ were moderately depressed. Research at Ambarawa Regional Hospital by Kuminingsih (2013) showed $37.7 \%$ patients with DM experienced mild depression, 
$35.8 \%$ had moderate depression, and $26.4 \%$ had severe depression.

Essentially, several factors such as physical, psychological, and social factors related to DM and its therapy may also trigger depression. Patients with DM who are depressed due to their chronic disease may experience depression (Supriati, et al. 2016). The lack of social support and feeling of denial towards their conditions may distress people with type 2 DM (Semenkovich et al., 2015).

Involving social support is one of the care management of depression associated with DM. Patient interactions with their social environment play a role in increasing their adaptation in accepting and controlling their disease. One of the social support forms is sfamily support (Isworo and Saryono, 2010).

A patient whose family is involved in the diabetes care will feel supported and motivated to cope with their condition. Patients with DM may feel physical and psychological comfort when receiving family support. It also helps them increase confidence to survive. Family is expected to always provide motivation, facilities and companionship to patients with DM, and thus they will feel loved and cared for doing activities independently (Supriati, et al. 2016).

Based on the issue above, this study identified depression tendencies that people with type $2 \mathrm{DM}$ experienced.

\section{METHOD}

This study applied a descriptive research design with a cross-sectional approach. It was conducted within 2 months starting from May to June 2019 in Kebonsari Primary Healthcare Center in Surabaya city. The research population included patients with type $2 \mathrm{DM}$ who underwent treatment in Kebonsari Primary Healthcare Center. The research samples involved were 74 people with type $2 \mathrm{DM}$. To be selected as the repsondents, patients were over 25 years old, had no history of mental illness, suffered from type $2 \mathrm{DM}$ for over five years or more, and were willing to participate in this study. While patients who were unwilling to participate were excluded from the list. The inclusive respondents were selected using a simple random sampling method.

This study utilized demographic and family support as independent variables and depression tendencies as a dependent variable. This study collected data through questionnaire-based interviews by visiting patients' hourse from doors to doors.

The demographic variables consisted of age, gender, education level, and complications. The age variable were then divided into two groups, namely adult age group (26-45 years old) and elderly group (46-65 years old). The gender variable was divided into male and female. The education level variable was categorized into low education (not attending school, elementary school, and junior high school graduates) and higher education (high school and university graduates).

The family support variable was measured using the Hensarling Diabetes Family Support Scale (HDFSS). This instrument was developed by Hensarling in 2009. It can measure patient's perceptions of family support they received so far. The family support variable consisted of some dimensions, such as emotion, appreciation, instrument, and information dimensions. It was poured into questions consisting of 29 items with alternative answers worth t 1-4 points. Family support was considered low if the score obtained was smaller than the mean (score of <76.9). While it was considered high if the score was the same or more than the mean (score of $\geq 76.9$ )

Furthermore, the depression tendency variable was measured using the Beck Depression Inventory (BDI) instrument created by Aaron T. Beck. This questionnaire 
was applied to measure how severe one's depression was, but it was not a diagnosis tool. The BDI questionnaire evaluated 21 depression symptoms which 15 symptoms described emotions, 4 symptoms described attitude change, and 6 symptoms were somatic symptoms. Each symptom was ranked on a 4-point scale, and its value was summed to give a total score of $0-63$. The assessment of depression tendencies wasbased on the scores obtained. A value or score of $<10$ indicated no depression tendencies (normal), 10-18 suggested a mild depression tendency, 19-29 indicated a moderate depression tendency, and >30 showed major depression tendency.The data analysis technique applied was the univariate analysis which presented the results in in frequency distribution tables narratively. This study has obtained an ethical proval from the Ethics Commission of Faculty of Public Health Airlangga University (No. 139/EA/KEPK/2019).

\section{RESULTS}

\section{Depression tendencies based on gender}

From gender perspective, depression tendencies mostly occurred to female respondents (47.4\%). Most female respondents $(33.8 \%)$ experienced a mild depression tendency, $9.5 \%$ felt a moderate depression tendency, and $4.1 \%$ tended to have severe depression. While of 23 male respondents, most of them did not experience depression tendencies. Only $2.7 \%$ of the male respondents experienced mild depression.

The results of depression tendencies are summarized in Table 1. The measurement of depression tendencies experienced by patients with type $2 \mathrm{DM}$ using the BDI questionnaire show that $50 \%$ of the respondents tended to experience depression.

Most respondents (36.5\%) experienced a mild depression tendency, $9.5 \%$ of them tended to feel moderately depressed, and $4.1 \%$ experienced a severe depression tendency.

Table 1. Depression Tendencies among Patients with Type 2 DM in Kebonsari Primary Healthcare Center.

\begin{tabular}{|c|c|c|c|c|c|c|c|c|}
\hline \multirow{3}{*}{ Variables } & \multicolumn{8}{|c|}{ Depression Tendencies } \\
\hline & \multicolumn{2}{|c|}{ Severe } & \multicolumn{2}{|c|}{$\begin{array}{c}\text { Moderat } \\
\mathrm{e}\end{array}$} & \multicolumn{2}{|c|}{ Mild } & \multicolumn{2}{|c|}{ Normal } \\
\hline & $\mathrm{n}$ & $\%$ & $\mathrm{n}$ & $\%$ & $\mathrm{n}$ & $\%$ & $\mathrm{n}$ & $\%$ \\
\hline \multicolumn{9}{|l|}{ Gender } \\
\hline -Male & 0 & 0 & 0 & 0 & 2 & 2.7 & 21 & 28.4 \\
\hline -Female & 3 & 4.1 & 7 & 9.5 & 25 & 33.8 & 16 & 21.6 \\
\hline Age & 2 & 2.7 & 1 & 1.4 & 3 & 4.1 & 5 & 6.8 \\
\hline $\begin{array}{l}-26-45 \text { уо } \\
-46-65 \text { уо }\end{array}$ & 1 & 1.4 & 6 & 8.1 & 24 & 32.4 & 32 & 43.2 \\
\hline \multicolumn{9}{|l|}{ Education } \\
\hline -Low & 2 & 2.7 & 4 & 5.4 & 22 & 29.7 & 18 & 24.3 \\
\hline -High & 1 & 1.4 & 3 & 4.1 & 5 & 6.8 & 19 & 25.7 \\
\hline \multicolumn{9}{|l|}{ Complicati } \\
\hline on & 2 & 2.7 & 4 & 5.4 & 22 & 29.7 & 9 & 12.2 \\
\hline $\begin{array}{l}\text {-Yes } \\
\text {-No }\end{array}$ & 1 & 1.4 & 3 & 4.1 & 5 & 6.8 & 28 & 37.8 \\
\hline \multicolumn{9}{|l|}{ Family } \\
\hline- & 3 & 4.1 & 6 & 8.1 & 22 & 29.7 & 15 & 20.3 \\
\hline \multicolumn{9}{|l|}{ Inadequate } \\
\hline - Adequate & 0 & 0 & 1 & 1.4 & 5 & 6.8 & 22 & 29.7 \\
\hline Total & 3 & 4.1 & 7 & 9.5 & 27 & 36.5 & 37 & 50 \\
\hline
\end{tabular}

\section{Depression tendencies based on age}

According to age groups, most respondents who experienced depression tendencies were in the age group of 46-65 years old (the elderly age group). Of 63 respondents in the elderly group, $41.9 \%$ of them experienced depression tendencies. As many as $32.4 \%$ of them experienced a mild depression tendency, $8.1 \%$ experienced a moderate depression tendency, and $1.4 \%$ experienced a severe depression tendency. 


\section{Depression tendencies based on education level}

The results show that the majority of respondents had low education (62.2\%). This study reveals $29.7 \%$ of them experienced a mild depression tendency, $5.4 \%$ of respondents experienced a moderate depression tendency, and 2,7\% others had a severe depression tendency.

\section{Depression tendencies based on complications}

Another variable discussed was complications. This study shows that the majority of the respondents who experienced depression tendencies previously had complications $(50 \%)$. In details, $29.7 \%$ of them experienced a mild depression tendency, $5.4 \%$ experienced a moderate depression tendency, and $2.7 \%$ others had a severe depression tendency.

\section{Depression tendencies based on family support}

Family support consisted of four dimensions, namely emotion, appreciation, instrument, and information dimensions. Based on Table 1, 62.2\% of the respondents received less family support. Among the respondents who received lower family support, $29.7 \%$ of them experienced a mild depression tendency, $8.1 \%$ experienced a moderate depression tendency, and $4.1 \%$ had a severe depression tendency.

\section{DISCUSSION}

Overview of depression tendencies in patients with type 2 diabetes mellitus

In Table 1, this study presents the prevalence of depression tendency in people with type $2 \mathrm{DM}$ was $50 \%$. It is in line with research conducted by Anderson et al., (2001) who find $48 \%$ of the respondents experienced depression due to DM. Further, research conducted by Mufidah (2018) shows that
$21 \%$ of the respondents experienced mild depression, $12 \%$ experienced moderate depression, and $18 \%$ felt severe depression.

In contrast, Ramdani (2016), who examined the level of depression of people with type $2 \mathrm{DM}$ at the Kardinah District General Hospital of Tegal district, shows mild depression occurred to $15.2 \%$ of the patients, $2.5 \%$ of the patients experienced moderate depression, and none $(0 \%)$ had major depression.

People who experience depression tendencies often feel upset and worried about the future due to their diseaseThey also experience sleeping disorders as they need to wake up to urinate at night for more than 3 times due to the high blood sugar levels. They also sometimes feel tired and less energetic.

Diabetes and depression correspond to each other. Depression can contribute to the inadequate control of diabetes. Diabetes and its complications also contribute to poor management of depression. Depressive events may have the risk of depression symptoms to appear again. A study shows a person with DM and depression is more prone to recurrent depression when being observed for five years (Lutsman, et al. 2000).

\section{Distribution of depression tendencies by gender perspective}

The results show that most depression tendencies occurred to female respondents (47.4\%). Ramdani (2016) shows similar results by mentioning that the percentage of depression tendencies in females was $53,2 \%$ higher than in males at $46.8 \%$. Research conducted by Ramanda (2014) also proves that the highest depression prevalence occured to females (20\%). Another study further finds depression prevalence was higher in female patients $(33.9 \%)$ than male patients (29.9\%) (Rajender, et al. 2016). A meta-analysis study conducted by Anderson, et al. (2001) discovers that diabetes increased 
the risk of depression twice higher in females $(28.2 \%)$ than males (18\%).

Depression is a psychological disorder related to long-term stressors such as chronic diseases, including diabetes mellitus. Men and women performa different attitudes to dealing with the stressors. as men tend not to be emotional in coping with a problem, they will prefer to solve a problem directly. Whereas women outweigh emotion, and thus it can make women more difficult to deal with stress (Mujabi, 2017).

\section{Distribution of Depression Tendencies from Age Perspective}

Based on the results, most respondents in the elderly group (aged 46-65 years) mostly experienced depression tendencies $(41.9 \%)$. In similar way, research by Ramanda (2014) states that a quarter of the respondents at the age group of 46-65 years experienced depression. Research conducted by Mufidah (2018) also indicates the highest depression tendencies occurred to patients with type 2 DM under 60 years old. High depression rates in this age group might be caused by a decrease in health and a sense of worry about the future. Depression may reduce patient motivation to seek for treatment and to practice self-care and cause their blood sugar to be uncontrolled and (Egede and Ellis, 2009).Female elderly have more possibilities to experience depression tendencies due to hormonal changes that cause menopause (Vamos, et al. 2009). Elderly patients with DM usually experience various health problems and undergo various kinds of health treatment. They generally feel alienated (isolated), worried about their future, declining health, and disability due to age (Rihmer and Angst, 2005). It is difficult to distinguish deterioration in elderly's physical condition due to the progression of the complications or old age.

\section{Distribution of depression tendencies based on education level}

Reagrding education levels, this study indicates the majority of respondents had a low education level (62.2\%). This is consistent with research conducted by Ramanda (2014) stating that the majority of respondents with low education experienced depression (20\%). However, it differs from research done by Sari (2016) pointing out the fact that the majority of respondents experiencing depression were highly educated (59\%).

According to Sativa (2015), there was a negative relationship between education level and depression tendencies in people with type $2 \mathrm{DM}$. The higher education level, the lower the degree of depression. Adequate education levels can help patients understand their condition, disease, and risks related to DM (Mufidah, 2018).

Research conducted by Rajender $\mathrm{et}$ al. (2016) shows that education level was associated with depression in people with type 2 DM. Low education level, especially illiteracy, may lead to lack of awareness of disease severity, routine medication, and dietary consumption which contribute to complications (Rajender, et al. 2016).

Depression often occurs in low-educated people with DM (Vamos, et al. 2009). Low education can correspond to low economy, indecent living place, unemployment, and difficulties to get a permanent job, which may encourage depression (National Collaborating Centre for Mental Health, 2010). Low education level was a risk factor for depression in people with chronic diseases, including diabetes mellitus. Lack of knowledge about the disease and its management, as well as insufficient exposure to information about coping mechanism may also cause depression (Supriati, Nasution and Ilmansyah, 2016). 


\section{Distribution of Depression Tendencies Based on Complication}

There were $37.8 \%$ of the respondents who had complications and experienced depression tendencies. These complications varied, such as high blood pressure, vision problems, leg injuries, and stomach disorders. Mufidah (2018) finds that the prevalence of depression and complications at the same time occurred to 51 patients (52\%). Anxiety and lack of knowledge may pressure a person to deny the changes that occur. As a result, a denial can worsen one's blood sugar control, thereby increasing the risk of complications and depression. Diabetes complications will cause nerve damage, increase blood viscosity, and impair the metabolism of fat (Mufidah, 2018).

Purwanti (2013) mentions when DM patients had wounds on feet, they would be at greater risk of experiencing depression than DM patients without wounds. Foot sores have caused unpleasant smell and often make patients feel inferior and ashamed. As a result, patients tend to isolate themselves and have difficulties to get along with neighbors. Research conducted by Rehman and Kazmi (2015) shows that there was high prevalence of depression, fear, and anxiety experienced by people with type $2 \mathrm{DM}$ complications.

\section{Distribution of depression tendencies based on family support perspective}

The results show that the majority of the respondents received inadequate family support $(62.2 \%)$, and nearly half of them experienced depression tendencies. Research conducted by Supriati, Nasution, and Ilmansyah (2016) finds that although the majority of respondents received sufficient family support, nearly half of them still experienced mild depression. Garousi and Garrusi (2013) state that supportive family behavior is a form of social support to avoid depression and anxiety to reduce stress. Interaction between patients and their families can change and improve the perception of the patients towards the disease more positively (Sari, 2016).

Family support also help DM patients more disciplined in maintaining the healthcare management (Mufidah, 2018). Lack of family support can cause incompliance with dietary restrictions; hence, the disease can be controlled (Susanti, 2013).

Family support and care will provide DM patients a sense of comfort, attention, compassion, and will foster patient to recover by accepting their condition. Another study conducted by Yusra (2011) finds that based on interviews with five people with type 2 DM, two of them had been exhausted with their condition for burdening their family, and three others had difficulty in practicing religious rituals and received less attention from their family. Family support can encourage patients to take their medication regularly according to the dose on doctor's instruction (Meidikayanti and Umbul, 2017).

\section{CONCLUSION}

A hald of total patients with type 2 DM in Kebonsari Primary Healthcare Center experienced depression tendencies. Most respondents who experienced depression tendencies were female and in the elderly age group (46-65 years old) and had low education levels and inadequate family support.

Family as the closest people to patients with DM should always provide adequate support by motivating, facilitating, and accompanying them so that they could calm themselves for accepting their condition and be encouragous to do their daily activities independently and manage their health.

\section{REFERENCES}

Anderson, R. J. et al. (2001) 'The Prevalence of Comorbid Depression in Adults with Diabetes: a meta-analysis', 
Diabetes Care, 24(6), pp. 1069-1078.

Centers for Disease Control and Prevention (2017) Diabetes.

Egede, L. E. and Ellis, C. (2009) 'Diabetes and Depression: Global Perpectives', Diabetes Research and Clinical Practice, 8(2), pp. 302-312.

Fatimah, R. N. (2015) 'Diabetes Melitus Tipe 2', J Majority, 4(5), pp. 93-101. doi: $10.2337 / \mathrm{dc} 12-0698$.

Garousi, S. and Garrusi, B. (2013) 'Does Perceived Family Support has a Relationship with Depression and Anxiety in an Iranian Diabetic Sample', International Journal of Caring Sciences, 6(3).

Handayani and Dewi (2009) 'Analisis Kualitas Hidup Penderita dan Keluarga Pasca Serangan Depresi', Psycho Idea, pp. 35-44.

International Diabetes Federation (2013) IDF Diabetes Atlas. Sixth edit, International Diabetes Federation. Sixth edit. Brfussels. Available at: www.idf.org/diabetesatlas.

Isworo, A. and Saryono (2010) 'Hubungan Depresi Dan Dukungan Keluarga Terhadap Kadar Gula Darah Pada Pasien Diabetes Mellitus Tipe 2 Di Rsud Sragen', Jurnal Keperawatan Soedirman, 5(1), pp. 37-46. doi: 10.20884/1.jks.2010.5.1.255.

Kuminingsih (2013) Hubungan Dukungan Emosional Keluarga dengan Tingkat Depresi pada Pasien Diabetes Melitus Tipe 2 di RSUD Ambarawa. Ungaran.

Lutsman, P. J. et al. (2000) 'Depression and poor glycemic control: a metaanalysis review of the literature', Diabetes Care, 23(7), pp. 934-42.

Meidikayanti, W. and Umbul, C. (2017) 'Hubungan dukungan keluarga dengan kualitas hidup Diabetes melitus tipe 2 di puskesmas pademawu', Jurnal Berkala Epidemiologi, 5(August), pp. 240-
252.

doi:

10.20473/jbe.v5i2.2017.240-252.

Indonesian Ministry of Health (2013) 'RISET

KESEHATAN DASAR 2013'.

Mufidah, S. (2018) Gambaran Tingkat Depresi pada Pasien Diabetes Melitus dengan Keluhan Penyerta di RSUD Dr. Moewardi Surakarta. Universitas Muhammadiyah Surakarta.

Mujabi, M. F. (2017) Hubungan Kadar Gula Darah dengan Tingkat Depresi dan Aktifitas Fisik pada Penderita Diabetes Melitus di Puskesmas gatak Sukoharjo. Universitas Muhammadiyah Surakarta.

National Collaborating Centre for Mental Health (2010) 'Depression, The Treatment anad Mangement of Depression in Adults (Updated Edition)', The British Psychological Society \& The Royal College of Psychiatrists.

National Institute of Mental Health (2011) Depression and Diabetes. Bathesda: National Institute of Mental Health.

Purwanti, O. S. (2013) Analisis FaktorFaktor Risiko Terjadi Ulkus Kaki pada Pasien Diabetes Melitus di RSUD Dr. Moewardi. Universitas Indonesia.

Rajender, A. et al. (2016) 'Study of Depression in Type 2 Diabetes Mellitus Patients', International Journal Medical Science and Public Health, 5(9), pp. 1874-1877.

Ramanda, R. (2014) Gambaran Tungkat Depresi Pasien Diabetes Melitus Tipe 2 di Puskesmas Purnama Pontianak Tahun 2013. Universitas Tanjungpura.

Ramdani, M. I. (2016) Gambaran Tingkat Depresi pada Pasien Diabetes Melitus Tipe 2 di Rumah Sakit Umum Kardinah Kota Tegal. Universitas Islam Negeri Syarif idayatullah.

Rehman, A. ur and Kazmi, S. F. (2015) 
'Prevalence and Level of Depression, Anxiety and Stress among Patients with Type-2 Diabetes Mellitus', Ann. Pak. Inst. Med. Sci, 11(2), pp. 81-86.

Rihmer, Z. and Angst, J. (2005) 'Mood Disorder: Epidemiology', Kaplan and Sadock's Comprehensive Textbook of Psychiatry. New York: Lippincott Williams \& Wilkins, 8.

Riley, A. A., McEntee, M. L. and Gerson, L. (2009) 'Depression as a Comorbidity to Diabetes: Implication for Management', Journal for Nurse Practicioners, 5(7), pp. 523-535.

Sari, I. N. I. (2016) Faktor-faktor yang Berhubungan Dengan Depresi Pada Pasien Diabetes Mellitus Tipe 2 Di Graha Diabetika Surakarta. Universitas Muhammadiyah Surakarta.

Sativa, O. (2015) Hubungan Tingkat Pendidikan dengan Derajat Depresi Pasien Diabetes Tipe II di RSUD Dr. Rivai Berau Kalimantan Timur. Universitas Muhammadiyah Surakarta.

Semenkovich, K. et al. (2015) 'Depression in Type 2 Diabetes Mellitus: Prevalence, Impact and Tratment', Drugs, 75(6), pp. 577-587.

Supriati, L., Nasution, T. H. and Ilmansyah, F. A. (2016) 'Hubungan Dukungan Keluarga Dengan Kejadian Depresi
Pada Pasien Diabetes Mellitus Di Rumah Sakit Muhammadiyah Gresik', Majalah Kesehatan FKUB, 3(4), pp. 183-189.

Surabaya City Health Agency (2018) Laporan Program Pelayanan Kesehatan Penderita Hipertensi dan Diabetes Melitus Bulan JanuariSeptember 2018. Surabaya.

Susanti, M. L. (2013) 'Dukungan Keluarga Meningkatkan Kepatuhan Diet Pasien Diabetes Melitus di Ruang Rawat Inap RS Baptis Kediri', Jurnal STIKES, 6(1).

Indonesian Ministry of Health (2014) Situasi dan Analisis Diabetes, Pusat Data dan Informasi Kementerian Kesehatan RI. doi: 24427659.

Vamos, E. et al. (2009) 'Comorbid Depression is Associated with Increased Healthcare Utilization and Lost Productivity in Persons with Diabetes: A Large Nationally Representative Hungarian Population Survey', Psychosomatic Medicine, 71(5), pp. 501-507.

Yusra, A. (2011) Hubungan antara Dukungan Keluarga dengan Kualitas Hidup Pasien Diabetes Melitus Tipe 2 di Poliklinik Penyakit Dalam Rumah Sakit Umum Pusat Fatmawati Jakarta. Universitas Indonesia. 